\title{
RUSSELL IN THE LORDS
}

\author{
KirK Willis \\ History / U. of Georgia \\ Athens, GA 30602-1602, USA \\ KW@ARCHEs.UGA.EDU
}

Bertrand Russell sat in the House of Lords as the third Earl Russell from 193I to 1970. In these nearly 40 years as a Labour peer, Russell proved to be a fitful attender and infrequent participant in the upper house-speaking only six times. This paper examines each of these interventions-studying not just the speeches themselves but also their genesis and impact within Parliament and without. Of all the controversial and important foreign and domestic issues faced by Parliament over these four decades, it was matters of peace and war which prompted Russell to take advantage of his hereditary position and, more importantly, of the national forum which the Lords' chamber provided him.

\section{INTRODUCTION}

$\mathrm{B}$ ertrand Russell's aristocratic lineage was central both to his own self-understanding and to the image his contemporaries-English and non-English alike-had of him over the course of his immensely long life. Although his patrician background added an undeniable exoticism to Russell's reputation abroad, within Britain it was central to his social position as well as to cultural expectation. No matter how great his achievement in philosophy or how wide his notoriety in politics, Russell's reputation-indeed, his very identity-possessed an inescapably aristocratic component, one best summed up by Noel Annan's celebrated judgment that alone of twentieth-century English- 
men Russell belonged to an aristocracy of talent as well as of birth. ${ }^{\mathrm{I}}$

Russell's patrician pedigree is, of course, well known and has been often described, not least by Russell himself in his many autobiographical writings. The achievements of his ancestors, the eccentricities of his kinsmen, the curiosities of his upbringing, and the privileges of his social position are thus well understood. Similarly important, of course, were the expectations of behaviour and assumptions of opinion that accompanied such a heritage — and here Russell himself confessed that at least part of the motivation for his lifelong political activism derived from a Whiggish assumption that he should not merely take an interest but give a lead in politics (PfM, pp. 48-9).

One place where the various strands of self-definition, political activism, and social expectation came together was in the House of Lords, where Russell sat as the third Earl Russell from I93I to 1970. As Russell recognized, the House of Lords offered him a unique national forum to speak directly on a range of pressing issues. Before the late 1960s, it is important to remember, Lords debates were carefully covered in the quality press. Not merely were lengthy verbatim extracts daily reprinted and leading articles devoted to the arguments and personalities involved, but the pronouncements of peers routinely served as headline fodder in the press and over the ввс. To a peer determined to address a wide audience, the Lords provided — until the advent of television—a unique opportunity to contribute to contemporary debate and to influence public opinion across a virtually limitless spectrum of issues. To Russell himself, the Lords promised, at least in theory, an audience far beyond the readership of his writings or the listeners to his broadcasts-and one willing to give him a hearing given his unique blend of aristocratic background, scholarly distinction, and cultural notoriety.

Russell became heir to his grandfather's earldom upon the latter's death in I878. Then age six and with an older brother himself only twelve, Russell's chances of ever succeeding as the third earl Russell in a then

I Noel Annan, "The Intellectual Aristocracy", in Studies in Social History, ed. J. H. Plumb (London: Longmans, I955), p. 28I. 
exclusively hereditary House of Lords must have seemed remote indeed. After going down from Cambridge in I894, Russell briefly flirted with a political career-largely to mollify his grandmother Russell, who hoped he would continue his grandfather's sacred work of reform-but the appeal and successes of academic life quickly lured him away from a public calling. To be sure, Russell—raised in a resolutely political household and accustomed to reading the political press all his life-retained a keen interest in political affairs - joining, for example, the Fabian Society and Coefficients, participating in pre-war campaigns in opposition to tariff reform and in favour of women's suffrage, canvassing in support of Philip Morrell's re-election to the House of Commons in I9IO, and, quixotically, running his own campaign in 1907 (albeit in irredeemably Tory Wimbledon). Even in those years when his energies were most fruitfully and single-mindedly focused on mathematical and philosophical work, Russell retained his abiding interest in contemporary British political life.

Such a heritage of aristocratic Whiggism and commitment to Edwardian Liberalism nearly won Russell a peerage in I9II in the midst of the bitter constitutional crisis provoked by the House of Lords' unprecedented veto of David Lloyd George's "People's Budget" of 1909. Presented by the self-appointed scourge of Britain's landed elite, that budget called for a sharp increase in death duties, an overhaul of the taxation of land values, and the imposition of a "super tax" on incomes of over $£ 5$, 000. The additional revenues raised by such reforms were to be applied to dramatically increased defence estimates and to expanded social spending (such as old age pensions). ${ }^{2}$ Taken by itself, this veto might not have incited the sensation that it did-culminating in two general elections in I9IO and in the passage of the Parliament Act in I9II (which greatly diminished the power of the Lords). Taken in the context of Edwardian party politics, however, it served as a catalyst to an unprecedented constitutional confrontation.

To Liberal laymen such as Russell and, most especially, to Liberal cabinet ministers such as Lloyd George and H. H. Asquith, the most

2 The financial and political contexts of the People's Budget are well described in Neal Blewett, The Peers, the Parties and the People: the British General Elections of I9Io (Toronto: U. of Toronto P., 1972), and Bruce K. Murray, The People's Budget 1909-1910: Lloyd George and Liberal Politics (Oxford: Clarendon P., 1980). 
infuriating feature of the Lords' action was not its novelty but its monotony. In the years since its sweeping electoral victory in January 1906, the Liberal Party had seen much of its most cherished legislation-over education, Ireland, licencing, plural voting-either vetoed or threatened by the Tory-dominated and electorally untouchable Lords. Exasperation among the Liberals had turned first to anger and then, after the first defeat of a budget since the reign of Queen Anne, to opportunity. To the Liberal leadership, the Lords had at once overreached and revealed their true selves - as indifferent to the nation's defence, hostile to social reform, uncaring of the opinion of the electorate, and selfish in their own narrow economic interests. The Asquith Government therefore hastened to a confrontation over a highly charged issue in which they were confident that they were at once morally in the right and electorally in the majority. They immediately proposed a reform of the House of Lords aimed at dramatically circumscribing that body's veto powers and, thereby, at permanently reducing its constitutional position. Certain of a Lords' veto of the proposed Parliament Act itself, Asquith took steps to secure the King's approval for the creation of sufficient new Liberal peers to pass the bill. Almost immediately after granting that authorization, however, Edward VII died, thereby further complicating an already fraught situation and prompting a new general election in December I9IO. For the political nation, a compelling drama was about to unfold.

As a loyal Liberal, Russell fully shared the indignation felt by party leaders over the Lords' obstructionism, and his private correspondence is full of evidence of both the close attention he paid to parliamentary politics and the high emotions the Lords' actions aroused in him. As a prominent non-office-holding Liberal, moreover, Russell soon found himself entangled - both willingly and unwittingly —in the political/constitutional crisis resulting from the veto. So well known was Russell, indeed, that he found himself involved in the struggle over the balance of forces in both the Commons and the Lords. As early as March I9IO, in fact, he was approached by a Liberal Party agent and asked to consider standing for the Oxford City constituency in the next election-a contest certain to be provoked by the inevitable Lords' veto of the proposed Parliament Act. Although he declined this particular invitation, Russell himself wrote to the Liberal Chief Whip to announce his desire to stand at the next election and to apply for a suitable constituency. By mid-April Russell's request had been passed along to the Liberal Associ- 
ation of the traditionally Liberal seat of Bedford—one, moreover, long associated with the Russell family. Following the customary practice of the day, that Association invited Russell to an interview with its committee and to address the full membership of the Association-a moment when he would be expected to outline the tenets of his political faith and to express his opinions on the major issues of the day. ${ }^{3}$

Although he was not ultimately selected to contest the seat, Russell did produce a revealing election address which allowed him to voice his political opinions and to order his political priorities in that highlycharged spring. ${ }^{4}$ Proclaiming that Britain was in the midst of the gravest political crisis since 1832 , Russell asserted that determining the proper constitutional position of the House of Lords was "the question which, at this moment, overshadows all others". Describing himself as "a whole-hearted supporter" of the proposed limitations on the Lords' veto power, Russell revealed that it was only his "sense of [the] urgent necessity" of constitutional reform that had induced him to consider abandoning his academic career and seek political office (Papers 12: 297). That Russell's deepest political instincts had been roused by the Lords' behaviour was clear throughout his address. Condemning the Lords' action as a "usurpation" and as "utterly intolerable to all who have reform at heart", he went so far as to charge that Britain's Tory peers had "attempted revolution" (I2: 297-8). His remedy was at once conventional and extreme. In the short term, Russell supported the proposed veto limitation; in the long run, he urged that the second house be transformed into a popularly elected body. Only after "the financial and legislative dominion of the Lords" had been swept away could the other reforms that Russell and the Liberals desired-women's suffrage, Irish Home Rule, land reform, and social insurance—be achieved (I2: 303).

Although in the event Russell did not contest Bedford or any other constituency in the December I9IO general election, he nonetheless played a role-albeit offstage-in the constitutional showdown resulting from the Liberals' narrow victory in that contest. As promised during the bitter campaign, immediately upon their re-election the Liberal Government introduced a parliament act-the chief provisions of which were to

3 The details of these transactions are well described in Papers 12: 294-6.

4 Russell's "Address to the Bedford Liberal Association" can be found in Papers I2: 297-303. 
prohibit absolutely the Lords' veto of any money bill and to limit their power to veto other legislation to two years. Central to the Asquith Government's strategy for overcoming the Lords' certain veto of this legislation was the threat to create sufficient new, Liberal peers to pass the bill. Such was the party imbalance in the 623-member Lords that Asquith and his advisors calculated that it would require the elevation of an astounding 250 new Liberal peers in order to guarantee passage of the Parliament Act. Once the newly elected House of Commons dutifully approved the act in the spring of I9II, the struggle moved on two interconnected tracks_-one public and one private. In public, the Lords faced an unhappy quandary-approve the proposed legislation and thus willingly abandon their chief constitutional power or oppose the legislation and have the Liberal Government swamp the House with the largest creation of new peers in that body's 700-year history. In private, the Asquith Government - having already secured a promise from George V to create the additional peers if the Lords' recalcitrance made it necessary-prepared its final list of proposed new peers. Because these new creations would be at once hereditary elevations (and thus, politically autonomous) yet expected to support the full Liberal agenda of Home Rule, social insurance, and land and education reform, great care needed to be taken in fashioning the final list. The new peers, that is, needed to be life-long and not just one-time Liberal voters-men who had demonstrated not merely mild liberal sympathy but strong Liberal loyalty.

It was not a surprise, therefore, that Russell's name was on the final list. Not merely was he a member of one of the oldest and most distinguished families of Britain's Whig/Liberal aristocracy and himself the heir to an earldom, but he had clearly and repeatedly demonstrated his Liberal fealty in his various electioneering activities since 1903. Party leaders therefore saw Russell quite rightly as a dependable Liberal voter in the Lords. It is perhaps not too fanciful, moreover, to suggest that they were not immune to two other features that would accompany Russell's elevation to the Lords-intellectual distinction and historical connection. Few members of the upper house had ever been fellows of the Royal Society and fewer still-in fact, only Russell's own brother, Frank-a grandson of the principal author of the epochal I832 Reform Bill.

In the event, the House of Lords chose not to die in the last ditch. Instead, variously grumbling, yielding to the inevitable, and breathing 
fire, they passed the Parliament Act by a slim margin and thus avoided the indignity of welcoming 250 unwanted colleagues. For Russell, this decision served merely to delay his eventual entry into the Lords, although it also forestalled him from using his seat there as a forum for criticizing Britain's role in the Great War. For students of modern British history, the Lords' concession robbed the upper house of a very distinguished intake, for on Asquith's list were such names as Gilbert Murray, Frederick Pollock, J. M. Barrie, Thomas Hardy, and Robert Baden-Powell-men who, in the words of Peter Clarke, "would actually have increased the calibre of any second chamber."

Russell succeeded to his grandfather's earldom on the death of his brother, Frank, on 3 March 1931. A proud, turbulent, and querulous personality, Frank Russell never discovered a true vocation, but rather succumbed to a succession of short-lived, largely fruitless enthusiasms - as barrister, electrical engineer, motoring pioneer, City gent, and bigamist. To the extent that he held genuine political convictions rather than mere passing intellectual fancies, his opinions usually ran in tandem with those of his younger brother-from advanced Liberalism before the war, to bitter and unrelenting opposition during the war, to avowedly Labour after 1918. For nine years in the i89os, for example, he served as a member of the London County Council as a Progressive and as an officer of the National Liberal Club. With the appearance of the short-lived first Labour Government in 1924, Frank Russell found himself, for all his waywardness, much prized as that rarest of political species-a Labour peer. ${ }^{6}$ Although the first MacDonald Government proved evanescent, Frank did show himself to be an articulate, if occasionally wilful, voice for Labour in the upper house. As a result, with the advent of the second

5 Peter Clarke, Hope and Glory: Britain 1900-199o (Harmondsworth: Allen Lane, 1996), p. 66. Another figure on the list was Russell's paternal uncle, Rollo Russell. A complete list of the prospective peers can be found in J. A. Spender and Cyril Asquith, Life of Herbert Henry Asquith, Lord Oxford and Asquith, 2 vols. (London: Hutchinson, I932), I: 329-3I.

${ }^{6}$ In 1920 there was precisely one Labour peer; by 1930 their number had swollen to seventeen (in a House of 753) (David Butler and Gareth Butler, British Political Facts 1900-1994, 7th ed. [London: Macmillan, 1994], p. 207). 
Labour Government in 1929, Frank found himself given minor officefirst as Parliamentary Secretary to the Minister of Transport and then as Parliamentary Under-Secretary in the India Office, which position he held at the time of his unexpected death on holiday in Marseilles. In contrast to his earlier unsteadiness, he had been an outstanding success at the India Office - skilled in bureaucracy, patient in administration, and articulate in debate. ${ }^{7}$ As unlikely as it may have seemed to anyone familiar with the irregular contours of his career, by the time of his death Frank Russell had become a reliable, useful, and not easily replaced member of the Labour Government.

Upon his succession as the third Earl Russell, therefore, Bertrand Russell faced several layers of expectation. By 193I he was, of course, universally regarded as one of the world's preeminent philosophers, and that reputation by itself would have made his sitting in the House of Lords a curiosity. Although never wholly without a stray academic or intellectual among its members, the Lords was rarely confused with an Oxbridge common room. A peer with Russell's academic credentials and international reputation would have been novelty indeed and insured him of a respectful hearing within and without the Lords' chambers. ${ }^{8}$ Nor, to come at the question of expectation from a quite different angle, had the Lords been home to many members who had been imprisoned for "statements likely to prejudice His Majesty's relations with the United States of America". Russell's bitterly unpopular anti-war writings and activities between I9I4 and I9I8, that is, had stigmatized him in the eyes of many of Britain's traditional political elite. Moreover, those few he had not outraged during the war, he had offended after it through his unorthodox writings on sexuality, marriage, education, and politics.

7 Frank even went so far as to ask his younger brother half-teasingly to join him: "I suppose you would not like to be made a peer and give a discriminating support to the Government? Your speeches would certainly ginger up the House" (Frank Russell to Bertrand Russell, I4 June I929, RAI 730). Frank Russell's official career is well described by a pair of obituaries: Manchester Guardian, 5 March I93I, p. IO, and The Times, 5 March I93I, p. 9.

${ }^{8}$ Another such intellectual peer was the eminent nuclear physicist Ernest Rutherford, who had been ennobled as Baron Rutherford of Nelson in the New Year's Honours List of 1931. In a letter of condolence of 9 March 193I Rutherford expressed his hope that Russell "will be interested enough to take some part in debates in the House of Lords in the future" (Auto., 2: 189). 
Although priding themselves on their customary practice of turning a blind eye to the political eccentricities and personal foibles of individual members, the Lords would thus have their legendary tolerance stretched to the breaking point. Finally, Frank Russell's recent success in the upper house only raised expectations concerning his heir still higher. In a body with scarcely two dozen Labour peers, Russell's presence would be valued simply as an attender, voter, and occasional speaker, to say nothing of serving as a minor office-holder. The Labour Party, itself scarcely thirty years old and in the process of displacing the irredeemably polarized Liberal Party as the major grouping on the political left in Britain, was at a distinct disadvantage in the overwhelmingly Conservative Lords. For Labour whips in the crisis-filled spring and summer of 1931, that is, every single body counted.

On Russell's part there is little evidence that he ever seriously considered taking an active role in the Lords. ${ }^{9}$ The early 1930 os were, of course, one of the lowest points in his fortunes as his marriage to Dora Black collapsed, their school at Beacon Hill seemed financially insatiable, and his chosen life as itinerant lecturer and man of letters proved at once successful and debilitating. In the aftermath of the cataclysm of the Great War, Russell had hoped to become the Voltaire of the twentieth century, Europe's conscience and peacemaker, and to work to remove not just the means but the impulses to war. As often in this fallen world, however, the demands of daily life and the weaknesses of the flesh soon overtook the aspirations of social reform and Russell found himself enmeshed in an unhappy marriage, in a failing school, in the writing of journalism he knew to be unworthy of his talents and corrupting of his

9 In an article accompanying the announcement of Frank's death, the Manchester Guardian's London correspondent repeated a rumour that "it has been suggested that the heir to the title, Mr. Bertrand Russell, might refuse to take his place in the House of Lords." After expressing his hope that Russell would see his way to participating in the Lords, the reporter concluded: "He is in any case a distinguished philosopher and scientist, by universal tribute an eminent intellect. How he would run as a member of a party is another question, and perhaps a difficult question with all this gifted family" (Manchester Guardian, 5 March I93I, p. 9). For his part, Russell seems never to have seriously considered abdicating his place in the Lords. As he mockingly told an American journalist in late October 193I when asked if he would take his seat after the requisite eleven months had passed: "I think so, but the difficulty is they only go to sleep when you talk to them" (New York Evening Post, 24 Oct. 1931, p. 6). 
self-respect, and in exhausting — albeit lucrative-lecture tours in Britain and, especially, in North America. At a very basic level, that is, Russell's life simply did not hold much room for an active role in the Lords.

Nor did Russell possess much respect for the Labour Government then in power. Facing an unprecedented economic and fiscal crisis in the wake of the collapse of the American stock market in October 1929, the MacDonald Government proved incapable of offering an economic policy based on anything other than the apparently now-discredited orthodoxies of nineteenth-century finance: maintain the Gold Standard, balance the budget, allow the economy to recover on its own terms and in its own time. Russell, it should be said, had long been grousing about Labour and its leaders, chiefly Ramsay MacDonald, Philip Snowden, and Arthur Henderson. In the aftermath of the bitter General Strike of 1926, for example, he condemned "the official Labour people" as "half scoundrels and the other half cowards", sentiments he repeated several years later when he judged that the Labour leadership was "doing nothing and has no programme". ${ }^{\text {IO }}$ It was the general timidity of Labour to which Russell objected. In his disillusioned view, Labour was too shy in offering a bold economic programme of its own, too modest in its assertion of socialism, too quiescent to the demands of international bankers, and too passive in its foreign and defence policies.

As disappointing as Labour might be, however, they were still superior to the now-moribund Liberals. Russell's own Liberal allegiances had not, of course, survived the war. Infuriated by the decision of the Asquith Government to join the fighting in I9I4 and enraged by its wartime mistreatment of conscientious objectors, suppression of civil liberties, hostility towards a negotiated settlement, and determination to send hundreds of thousands of young men to the slaughter, Russell had angrily renounced his faith in a party of which he had thought better. This apostasy was not simply personal-although his antipathy to Lloyd George was scarcely rational-it was also principled, for during the war Russell had come to believe that the familiar nineteenth-century Liberal creed in which he had been raised had itself been in part responsible for the misery of the war. By war's end his allegiance had shifted not merely

Io Russell to Ottoline Morrell, i5 June 1926, and Russell to Dora Russell, 30 January 1932 (SLBR, 2: 256, 308). 
from Liberal to Labour but from liberalism to socialism. For all of Labour's manifest inadequacies, after I9I8 it was the only political party Russell could even consider supporting. . ${ }^{\text {II }}$

Despite such constraints, immediately after his succession to the peerage Russell was at least prepared to entertain the prospect of some kind of role in the Lords. Thus when his friend of 40 years Sidney Webb, himself ennobled as Baron Passfield and serving in the Labour Cabinet as Colonial and Dominions Secretary, combined a letter of sympathy with the suggestion that the two meet to discuss party strategy in the Lords, Russell accepted. ${ }^{12}$ Although their specific political conversation went unrecorded, Beatrice Webb left a striking portrait of Russell in her diary:

Bertrand Russell, now an Earl, lunched here on Sunday to talk over his new role as a Labour peer.... What interested me was the change in Bertrand; he looked wretched. I watched his expression and tried to describe it in words. Is it sheer disgust, a sort of savage resentment? He has lost the sardonic liveliness, the cheerful and witty cynicism of the first years of his marriage [to Alys Pearsall Smith in the I89os].... Poor Bertie; he has made a miserable mess of his life and he knows it. ${ }^{\mathrm{I3}}$

Despite these characteristically overdrawn observations, the Webbs doubtless also conducted some Lords' business with Russell-such as explaining that he would need to wait eleven months from his brother's death until he could take his seat, that he would need two sponsors to present him to the Lords at that time, and that he would need to acquire a high tolerance for the snail's pace at which the upper house's business was traditionally transacted.

${ }^{\text {II }}$ Russell had signalled his apostasy by standing as the Labour candidate for intractably Tory Chelsea in the 1922 and 1923 general elections. Alas for Russell as well as for Dora in the 1924 election, voters in their home constituency proved unshakable in their Tory faith.

I2 "When may we hope to welcome you to the House of Lords", Webb asked, before warning Russell unappetizingly that "it is a deadly dull assembly with no rules, but habits; and these are dilatory in the extreme. I never saw a place in which so little was done in so much time. But it may give us more opportunities of meeting" (Sidney Webb to Russell, I4 March I93I, in The Letters of Sidney and Beatrice Webb, ed. Norman Mackenzie [Cambridge: Cambridge U. P., 1978], 3: 348).

I3 The Diary of Beatrice Webb, ed. Norman and Jean Mackenzie (Cambridge, Mass.: Harvard U. P., I985), 4: 244. The second ellipsis is in the original. 
This unsatisfactory session was reflected in Russell's correspondence with Lord Marley, the chief government whip in the Lords, who wrote to inquire about the role Russell hoped to play there. Russell's reply was doubtless disillusioning to Marley. "I hope to take my seat before very long and I shall be a supporter of the Labour Party", he answered. But as for assuming a role comparable to that of his brother, to say nothing of committing to frequent attendance or speaking, "I do not ... expect to attend regularly or to give a very great deal of time to politics" (quoted in Clark, p. 437). As a former naval officer with a flair for command as well as experience dealing with reluctant and dithering peers, Marley was not easily put off, and Russell's candour served only to embolden Marley to try harder to gain his new charge's participation on the desperately short-handed Labour benches. By pestering his new recruit so vigorously, however, Marley served only to exasperate Russell and to confirm him in his refusal to adopt an active role in the Lords. As he complained to his old anti-war friend and Labour stalwart Fenner Brockway:

It seems that Marley is a very vigorous Whip. He has been inundating me with letters practically saying that if I go out for the afternoon I must telegraph to him to say where I am going. I do not, however, intend to take much part in the affairs of the House of Lords. I shall take my seat, and probably once in a way speak on issues which are inconvenient for people with constituencies, such as divorce and obscene literature. But I do not intend to be turned aside by an accident from writing, which is clearly my proper job. (Clark, p. 437)

Such a disinclination to play an active role in the Lords disappointed many of Russell's old friends, some of whom doubtless relished the prospect of an ermine-clad FRS rousing the Lords from their slumbers. In a letter of condolence, Russell's old pre-war friend and war-time antagonist Gilbert Murray, for example, urged him to seize the opportunity of reaching an audience far wider than any of his books could achieve and to speak his mind early and often. "I believe that the sort of thing you have to say to the world ought to be said - and said repeatedly", pressed Murray, and especially in a forum "where you can get a pulpit to address the country, instead of merely inspiring intellectual socialists and the like". Although flattered by Murray's praise- "you have more courage than I, as well as more power of intellect"-Russell was unwilling to be swayed: 
I shrink from the thought of addressing so hostile an audience as the Peers, and I cannot in any case do as [Frank] did on behalf of the Government, even if the Government desired my support. I am too dissatisfied with them in many respects to be able to become a loyal Party man. I like their conduct of foreign affairs and their concordat with Gandhi, but not their complete inaction at home. (Ibid., p. 437)

By the time Russell came to take his seat-sponsored in the event by Sidney Webb and by his old Cambridge friend Charles Trevelyan-circumstances had combined to upset nearly all these calculations. Chief among the changes was the replacement in August 193I of the all-Labour MacDonald Government by an all-party National Government, itself also headed by Ramsay MacDonald. This sudden change in political fortune had been prompted by the inability of the Labour cabinet to agree on a budget in the Depression-struck summer of 193I. Caught between loyalty to its working-class constituents and obedience to the strictures of orthodox political economy, the Labour cabinet had found itself unable to agree to the swingeing spending cuts-chiefly in unemployment benefits-necessary to produce a balanced budget. The Labour cabinet had therefore resigned, only to be unexpectedly and controversially replaced by a coalition cabinet headed by the former Labour Prime Minister but filled with Conservative and Liberal colleagues perfectly prepared to make the savage budget cuts at which their Labour predecessors had balked. In an election held in October 193I to ratify the draconian budget the coalition had triumphed, gaining 556 seats (472 of which were Tory) to 56 for Labour. By the time Russell took his seat in March 1932, therefore, MacDonald had been expelled from the party he had done more than any other individual to create, and his former followers found themselves pathetically outnumbered in Parliament and hopelessly in opposition. ${ }^{14}$ Russell, a sharp critic of MacDonald's "betrayal", therefore entered the Lords still as a Labour peer, but now as an opposition rather than a government supporter-whipped by the same Lord Marley but in a politically quite useless position. ${ }^{15}$

${ }^{14}$ A good guide through the political labyrinth of the early I930s is Philip Williamson, National Crisis and National Government: British Politics, the Economy and Empire, 1926-1932 (Cambridge: Cambridge U. P., 1992).

is Russell took the formal oath in late March 1932. The Labour-leaning Daily Herald had made a premature announcement, born more out of eagerness than inside infor- 
Under the circumstances, it is hardly a surprise that a full five years passed before Russell made his maiden speech in the Lords. The occasion of that intervention was a full-dress debate on foreign policy opened by Sydney Arnold, a former Liberal MP who had joined the Labour Party in 1922 and served as Paymaster General in the second Labour Government. A long-time sceptic concerning the League of Nations and its promise to provide for the collective security of Europe and the world beyond, Arnold was especially upset by the recent decision of the $\mathrm{Na}-$ tional Government to increase Britain's defence estimates in response to German rearmament, Italian buccaneering, and Spanish insurrection. Alarmed by the apparent blindness of the Government to what he judged to be the obvious lessons of the Great War-entangling alliances, arms build-ups, and nationalistic sabre-rattling-Arnold tabled a motion on the direction of Britain's foreign policy and then led off a spirited debate in an unusually full and attentive House. ${ }^{16}$ Although his arguments were wearisomely detailed and intricate, Arnold's message was unambiguous:

I submit that it becomes more and more clear that the whole policy of commitments on the Continent, even to France, is wrong and that all such commitments ought to be brought to an end.... We ought, I contend, to do what Belgium has done and declare that in future our policy is to place ourselves outside

mation, a month before under the headline "Lord Russell's Seat: Lord Russell, formerly Mr. Bertrand Russell, will take his seat in the House of Lords early next month. 'I shall not stay there,' he told the 'Daily Herald' yesterday. I shall not let it interfere with my writing'” (Daily Herald, 23 Feb. 1932, p. 2). For his part, Russell told Dora on 20 March that "all the formalities have been completed" and that he would "be taking my seat some day soon" — as he did (Russell to Dora Russell, SLBR, 2: 313).

I6 The twentieth-century House of Lords was a place of virtually no spontaneity and scarcely any genuine debate. Members-as well as the Government of the day-could propose items for the agenda, which was itself set by the Government-appointed Leader of the House. After the agenda paper was circulated among members, usually some days or even weeks in advance of the actual debate, members would put themselves down as desiring to speak to the motion at issue. Speakers were thus prearranged, and every peer who put his name down and appeared on the day was able to speak. Russell's appearances in the Lords were thus chosen in advance and in the certain knowledge that he would be able to speak. Small wonder, therefore, that Russell like most of his colleagues prepared talking points in advance of his interventions and spoke from them. His surviving remarks as printed in the Lords Debates were thus subjected to the usual silent emendations of style, sense, and syntax done by Hansard reporters. 
any disputes of our neighbours.... The time has come in my submission, and is indeed overdue, when Great Britain ought to withdraw from these interminable and insoluble quarrels and feuds on the Continent. We ought to get out and keep out. ${ }^{17}$

As intended, such provocative views prompted a lively three-day debate, with peers of every party and persuasion weighing in and with the full range of Britain's press paying close attention. One of the earliest participants was Russell, who used the opportunity afforded by Arnold's motion to make his maiden speech. Preparing his remarks carefully in advance, Russell repeated many of the same arguments he had been making throughout the I930s in essays, newspaper articles, speeches, and, most fully, in Which Way to Peace? (1936). Pausing only to offer the customary courtesies to Arnold, Russell hurried to present his familiar critique of the National Government's rearmament programme. The only two sensible criteria by which any such programme can be judged, Russell opened, are, first, is it "likely to promote peace" and, second, "if it fails to preserve peace, will it preserve the civilian population in this country from very appalling disasters." ${ }^{28}$ With regard to the first criterion, Russell argued that the Government's chief argument in favour of a dramatic increase in defence estimates - that Britain's defences were badly antiquated and run down-would serve only "to stimulate people, who are in any case inclined to think of war, to go to war soon rather than late". Far from deterring or preventing a war, that is, the Government's policy was much more likely to provoke one. And as to the second criterion of sound policy, Russell proclaimed that a war fought with the newest technology of airplanes, poison gas, and modern artillery would inevitably inflict huge civilian casualties in Britain and in every combatant nation. Indeed, "what is going to be called victory in the next war will be something so horrible and so appalling that it will be only a trifle worse than what would be called defeat" (cols. 319-20). Thanks to these "improvements" in the art of warfare, Russell observed sharply, "nobody is going to be any the better for the next war, neither the victors nor the vanquished." The next European war will therefore

17 "Foreign Affairs", Parliamentary Debates (Lords), (5), I04 (24 Feb. 1937): cols. 297-8.

${ }^{18}$ Ibid., cols. 318-I9. 
be not merely an "atrocity", but an "insane atrocity"—one which Britain should avoid provoking or participating in at any cost. As Russell summed up:

I should like, myself, to see our own country standing outside that atrocity and saying that, whatever cost there may be to be paid, we will be neutral, we will stand outside this horrible network of threatenings of war. I should like us to say, "No, we would rather suffer some loss, some damage, some inconvenience, from neutrality, than come in to form a part of this abominable shameful thing that modern war has become." (Col. 322)

Russell was enough of a celebrity that his maiden speech did not go unremarked. To his audience within the Lords, it marked an occasion to welcome him formally to the body. For example, the former diplomat and Chairman of the Conservative Party Organization, Lord Stonehaven, paused in his remarks to welcome Russell to the upper house and to pretend a genuine interest in the latter's argument, "a point of view which perhaps is not widely shared" but which Russell had expounded "in the most charming and lucid and obviously sincere manner" (col. 324). For his part, the former Labour MP and prospective Opposition Chief Whip, Lord Strabolgi, welcomed Russell to the Opposition benches, praised his "felicitous" remarks, and confessed himself to be "one who many times has sat at his feet as a humble disciple". Such deference did not, however, prevent Strabolgi from condemning Russell's impassioned argument as "the faith of the Ioo per cent Christian pacifist, that nothing can be worse than war and that therefore at all costs one should not fight" - a view which the former Royal Naval officer dismissed out of hand (col. 330).

To the press, Russell's intervention also had the merit of novelty and controversy. The diarist Peterborough, in the Conservative Daily Telegraph, for example, highlighted Russell's appearance in a brief column titled "Pacifist Peer's Maiden Speech":

An attentive House listened to him without interruption, but in "another place" [the Commons] he would probably have been called to order for irrelevancy. His academic discourse on the horrors of war and the folly of the defence programme had little bearing on Lord Arnold's motion.... Socialist cheers, hearty at first, died away into silence as Lord Russell developed his pacifist theory. 
Peterborough also noted disapprovingly that Russell's "dry, precise style" contrasted unfavourably with the "courteously persuasive tones" of his brother, "whom he succeeded six years ago". 9 Similarly, in a leading article devoted to "Foreign Policy", the Manchester Guardian paused to make mention of "the expression of two individual and unpopular views. Lord Arnold opened the debate by stating the case for 'isolation', and Lord Russell spoke for that national pacifism which he has so brilliantly advocated in his book 'Which Way to Peace?'”20 In its lengthy report on the debate the Liberal Guardian, a paper much more sympathetic to Russell than the Tory Telegraph, signalled out his intervention for special praise:

Incomparably the most notable speech was that of Earl Russell, better known, of course, in other days as Bertrand Russell. He agreed with Lord Arnold's policy of isolation, and utterly condemned the great expenditure on arms.... So appalling will be the next war, said Earl Russell, that the civilian population will rise up and refuse to let it continue. ${ }^{2 \mathrm{I}}$

To Russell himself, his maiden performance in the Lords was overshadowed by increasingly complex family demands. By the spring of 1937 his new wife, Peter Spence, was heavily pregnant and the money to run a second household had to be found. Attempts to secure an academic position in Britain proved fruitless - among his many other disadvantages, Russell was now nearly 65-and his usual source of quick income-an American lecture tour-was much less attractive given his necessary absence during Peter's pregnancy and the financial constraints of Depression America. By the autumn, however, conditions had brightened considerably-Telegraph House had been sold, a son, Conrad, had been safely born, and an academic position found at the University of Chicago-where Russell and his new family moved in September 1938.

Russell's time in America proved far longer and much more troubled than he or anyone else could possibly have foreseen. ${ }^{22}$ Although he ar-

19 Daily Telegraph, 25 Feb. 1937, p. I6.

20 Manchester Guardian, 26 Feb. 1937, p. I0.

${ }^{21}$ Ibid., 25 Feb. 1937, p. II. Snippets of Russell's remarks also appeared in The Times, ${ }_{25}$ Feb. 1937, p. 13, and Daily Express, 25 Feb. 1937, p. 2.

${ }^{22}$ Russell's travails in America are well described in Clark, pp. 465-87, and Monk, 2: 219-73. 
rived there angry at the foreign and domestic policies of successive $\mathrm{Na}-$ tional Governments and eager for a spell of comfortable exile away from Britain, the outbreak of war in September 1939 stranded him in North America. Desperate to return to Britain in its time of supreme national peril and bedevilled by a succession of personal and professional crises in America, Russell would nonetheless be forced to spend nearly the entire war in the United States. To his dismay, the Foreign Office proved deaf both to his pleas that he be allowed to return and to his assurances that, unlike during the conflict with the Kaiser, he was a loyal supporter of the war against Hitler. So anxious was Russell to be permitted to return, indeed, that-in addition to the usual begging letters and efforts at wire-pulling by well-placed friendsa member of the House of Lords he should be allowed to return in order to uphold his legislative responsibilities:

I went to Washington to argue that I must be allowed to perform my duties in the House of Lords, and tried to persuade the authorities that my desire to do so was very ardent. At last I discovered an argument which convinced the British Embassy. I said to them: "You will admit this is a war against Fascism." "Yes", they said; "And", I continued, "you will admit that the essence of Fascism consists in the subordination of the legislature to the executive." "Yes", they said, though with slightly more hesitation. "Now", I continued, "you are the executive and I am the legislature and if you keep me away from my legislative functions one day longer than is necessary, you are Fascists." Amid general laughter, my sailing permit was granted then and there. (Auto., 2: 224)

Although this account sounds rather too good to be true, Russell did duly arrive in Britain the week after D-Day_clutching the mammoth manuscript of what would become his most widely read book, A History of Western Philosophy. Russell returned not simply to England but to Cambridge, and not merely to Cambridge but to Trinity College-where he had been an undergraduate in the I890s and a don in the I9Ios, and from which he had been driven in 1916 by a governing body unable to tolerate his anti-war opinions. Invited by his old undergraduate friend and the current Master of Trinity, G. M. Trevelyan, Russell had recognized and happily accepted the fellowship offered him for what it wasan amends for earlier wrongs and a testimony to his continued standing as one of the preeminent philosophers of the twentieth century. To return to England, to Trinity, to Newton's own rooms in the immediate 
aftermath of the invasion of France and final stages of the defeat of Germany meant much to Russell, who had left the Britain of the late I930s sour and despondent. But by 1944 that low, dishonest decade had passed, and the quick succession of Allied victory, Labour triumph, and publishing success of $A$ History of Western Philosophy, all combined to restore Russell's natural high spirits.

At Cambridge Russell was warmly received by old friends and those few students not in military service. With the war's end in May 1945, followed hard by Labour's victory in July and the History's success, Russell found himself lionized. Coming as it did after the unexpectedly bitter interlude in America, such acclaim was doubly welcome, and Russell took full advantage of his new celebrity-lecturing to overflowing halls in Cambridge, broadcasting over the ввС's Home and Foreign Services, and even touring post-war western Europe under Foreign Office auspices. Added to his normal steady output of articles, interviews, and speeches, such activity consumed most of Russell's still considerable energies. Nonetheless, he did twice make time to travel to London in the late autumn of 1945 to take up - at least nominally - the legislative functions he had mockingly described as so pressing to the authorities in Washington.

Russell's first appearance in the Lords in nearly nine years came in the midst of a two-day, full-dress debate on "The International Situation" on $27-28$ November $1945 .{ }^{23}$ Launched by the Leader of the Opposition, Viscount Cranborne, the debate was intended to be both wide-ranging and non-partisan and to allow the Lords to rove freely over the complicated and unsettled state of the world in the first months of peace. Expectations were fully met as some of the Lords' heaviest hitters-from former cabinet ministers such as Herbert Samuel and Samuel Hoare, to church worthies such as Archbishop Cyril Garbett and Bishop George Bell, to Labour leaders such as Christopher Addison and Lord Strabolgi, to Opposition spokesmen such as Lord Llewellin and Lord Cherwell, to professional men of peace such as Viscount Cecil and Lord Pethick-Lawrence-weighed in on issues stretching from Palestine to India, disarmament to the United Nations.

23 “The International Situation”, Parliamentary Debates (Lords), (5), I38 (27 and 28 Nov. 1945): cols. 17-64 (27th), 68-I37 (28th). 
Russell's intervention came early in the second day of debate and focused on an issue about which he had already said much and on which he would both say and write a great deal more in the next two decadesthe atomic bomb. Pleading diffidence, acknowledging inexperience, and, unusually for a man of such supreme intellectual self-assurance, feigning ignorance, Russell explained his unusual appearance in the House rather coyly. It was, he proclaimed, only because the release of atomic power "is so important and weighs so heavily upon my mind that I feel almost bound to say something about what it means for the future of mankind." The source of his anxiety, Russell explained, derived from two much-dreaded prospects- the inevitable technical improvement of nuclear weapons and their certain proliferation among major industrial nations. On the first count, Russell offered an early public foreshadowing of the development of a hydrogen bomb-a weapon, as he explained, in theory limitless in its destructive capacity and indiscriminate in its effects. By way of illustration he offered a "nightmare vision" of "St. Paul's, the British Museum, the Houses of Parliament and other monuments of our civilization ... as heaps of rubble with corpses all round them". ${ }^{24}$ On the second count, Russell explained that the technology of nuclear weapons manufacture was not in fact especially difficult and that the spread of nuclear weapons beyond the direct control of the United States or Britain was a certainty. If the world did not want to face an unprecedently dangerous arms race, action was therefore imperative.

As to prescriptions concerning such action, Russell offered two observations-one philosophical, the other diplomatic. The philosophical reflection-and one to which Russell confessed that he had no special insight-was whether advanced technological societies can avoid selfannihilation at the hands of their own creations: "Is it possible for a scientific society to continue to exist, or must such a society inevitably bring itself to destruction" (col. 89). Labelling this "a simple question but a very vital one", Russell chose not to address it directly but instead to subsume it into the larger political and diplomatic question of how "to find a way of abolishing war". Although conceding that such a question could be answered either psychologically, economically, militarily,

${ }^{24}$ Parliamentary Debates (Lords), (5), I38 (28 Nov. 1945): cols. 87-8. 
or diplomatically, Russell focused his contribution to what was after all a debate on the international situation on how best to achieve some kind of genuine and effective international control of nuclear weapons technology. And, again practically, he confined himself not to the fashioning of an ideal international organization of world government but rather to the refitting of the already existent United Nations so as to allow it to direct and monitor the civilian and military development of atomic energy world wide. Moreover, as Russell candidly pointed out, the immediate issue was how to make certain that the likeliest nation to develop atomic technology, the Soviet Union, could be forestalled from doing so through the agency of the UN (cols. 89-90).

Russell's own proposals to this end were at once brief and bold. The essential point, he emphasized, was to make the Russian Government "see that the utilization of this means of warfare would mean destruction to themselves as well as to everybody else" - an appreciation to be gained through candid diplomacy and plain-speaking commentary by the West. Furthermore, the pervasive "atmosphere of suspicion" between East and West "can only be got over by complete and utter frankness." And crucial to that candour were both sides' scientists-all of whom, Russell claimed, were at once uneasy over weapons research, informed about technical matters, sensitive to proliferation and inspection issues, and "thankful if some task could be assigned to them which would somewhat mitigate the disaster that threatens mankind." In sum, Russell concluded, the indispensable precondition to the creation of international control of atomic energy and thus to the avoidance of an otherwise inevitable nuclear cataclysm was not technical or diplomatic but psychological. Without the will of the Russian regime behind its workings, even the most technologically adept and politically sophisticated international scheme would fail; with such a will, by contrast, "it will be easy to manufacture the machinery" (cols. 90-2).

Russell's brief remarks raised many issues about which he had already written and to which he would return, often amidst much controversy, over the next two decades. On the day, his speech seems to have fallen rather flat. No other peer rose either to take issue or to register agreement with Russell's line of reasoning, beyond the usual pious expressions of respect. And press reporting was distinctly modest as well, as most of the major dailies and all of the weekly magazines focused their attention on the arguments presented by government spokesmen, opposition 
critics, and former foreign secretaries. One major exception was the Conservative-minded Daily Telegraph, which awarded Russell's remarks pride of place under a news-page headline: "Earl Russell's Warning on Atomic Bomb: Man Must Solve Problem or Drop Out”. Remarking that Russell's appearance was only "the second ... in his life and after a long absence", it reported that the House had "listened with great interest" to Russell's arguments - which it quoted in considerable detail. It did not, however, see fit to refer to Russell in its leader on the debate. ${ }^{25}$

Remarkably, Russell waited not another seven years but only a scant seven days before making another appearance in the Lords. The occasion was a brief debate on "The Situation in Central Europe" led by two unlikely allies for Russell - the Archbishop of Canterbury, Geoffrey Fisher, and the Bishop of Chichester, George Bell. At issue were not lofty questions of Great Power rivalry but rather mundane matters of daily existence-what Fisher, in his opening remarks, described as "the acute distress prevailing in Europe" in this first, bleak winter of peace. After six years of unprecedentedly destructive warfare, the Archbishop reported, central Europe was a ruin, incapable of feeding or sheltering itself and facing a pitiless winter of shortages of food, medicine, clothing, and housing. In prospect, he declared, was a nightmarish six months wherein those who had managed to survive the war itself would perish in the harsh circumstances of peace. ${ }^{26}$

Fisher's purpose in raising this issue was at once to alert the British public to these desperate conditions, to urge the British Government to do all it could within its zone of occupation to improve matters, to call for the donation of food, clothing, and money by individual Britons to relief agencies, and to remind the British people of their Christian duty to love their former enemies as themselves - even, indeed perhaps especially, in times of real stringency within Britain itself. For his part, Bishop Bell, who had been a lonely and controversial critic of the Allied obliteration bombing campaign over Germany during the war, echoed the Primate's arguments and offered his own eye-witness confirmation of the misery, destruction, and despair to be found across central Europe (cols. 369-76).

${ }^{25}$ Daily Telegraph, 29 Nov. 1945, p. 6. The Times also mentioned Russell's intervention in its parliamentary report on 29 November 1945 , p. 8.

26 "The Situation in Central Europe", Parliamentary Debates (Lords), (5), I38 (5 Dec. I945): cols. 34I-8. 
Russell chose to intervene in this discussion simply to lend his support to the remarks made by his ecclesiastical colleagues. Taking the desperate conditions as given, Russell declared that he wished to "confine myself, as far as I can, to practical points, to what can actually be done" to save lives and alleviate conditions. None the less, he paused at the opening of his rather brief remarks to urge the Attlee Government to generosity. Declaring himself "a whole-hearted supporter of the present Government both in their foreign policy and in their home policy", Russell none the less criticized what he termed "a certain grudging spirit" among ministers and officials, men who behaved "as though they were looking to see, not how much we can do, but how little" (cols. 377-8). That mild rebuke delivered, Russell turned to practicalities and suggested that the Government do all it could to expedite the sending of civilian food parcels from Britain to Germany, to use army transport to move goods and fuel in the British zone, to distribute the 75,000 surplus army blankets then on sale in Britain to Germany instead, to develop schemes to bring refugee children to welcoming families in Britain-in sum, to "be a little more sympathetic" and imaginative in the face of "this appalling calamity" (cols. 379-80).

Such worthy sentiments won a friendly reception in the Lords as well as in the press. Although other speakers offered more authoritative accounts of conditions on the ground in Europe and of the complex logistic difficulties faced by the upstart United Nations Refugee Relief Agency, nearly all of them endorsed Russell's suggestions as both worthy and practicable. For its part, the British press registered both the debate itself and Russell's fleeting intervention approvingly, although no paper seems to have judged the issue to merit a leading article. ${ }^{27}$

By contrast, Russell's next appearance in the Lords was on an issue of intense contemporary interest - the international control of atomic energy. In the immediate aftermath of the Japanese bombings and the close of the war, the issue of the control of atomic weapons had become one of acute international concern and controversy. With the passage of time and the chilling of attitudes between what was now dubbed the East and the West, the issue of the proliferation of nuclear technology emerged as a central part of that cluster of disagreements known as the

27 See, for example, Daily Herald, 6 Dec. 1945, p. I, and The Times, 6 Dec. 1945, p. 6. 
Cold War. By the late spring of 1947 the prospect of an all-out UsSoviet nuclear arms race seemed quite real and threatened to complicate ongoing rivalries over Eastern Europe, Asia, Germany, and the Middle East. To forestall that grim prospect, efforts had been and were continuing to be made across the world by officials, scientists, diplomats, and others to fashion some sort of international agreement that would give the nascent United Nations Atomic Energy Commission monopoly control over nuclear technology for civilian as well as military applications guaranteed by strong enforcement provisions.

The most important of these proposals had been the so-called Baruch Plan, named after the American financier Bernard Baruch who had presented it to the United Nations in June 1946. Offered on behalf of the American Government, the Baruch Plan endorsed the creation of the UNAEC, entrusted it with exclusive control not merely over raw materials but also over the construction, inspection, and operation of reactors and separation plants worldwide, and provided that states found in violation of the agreement should be punished, regardless of any right of veto by the permanent members of the UN Security Council. ${ }^{28}$ In response, the Soviet Union had countered by calling for an international convention banning the production, stockpiling, and use of atomic weapons. Existing weapons stocks - of which the United States was the sole possessor-were to be destroyed and signatory states were to enact legislation providing harsh penalties for breach of the agreement. As always with such intricate issues, the devil was in both the details and the timetable. The United States_-and its British ally—sought not a mere convention outlawing atomic war, but instead an international authority armed with a robust inspectorate that would rely on more than the good intentions of member states for its effectiveness. The Soviet Union, by contrast, opposed any intrusive inspection regime and trusted instead to the honesty and goodwill of the signatories. The real division between the two proposals, however, had to do with their timetables. To accept the American proposal meant that all other nations would have to forego

${ }^{28}$ The Baruch Plan and the endless diplomatic wrangles it provoked have been much discussed. Two of the best treatments are in Gregg Herken, The Winning Weapon: The Atomic Bomb in the Cold War 1945-1950 (Princeton: Princeton U. P., 1988), pp. 151-91, and Richard G. Hewlett and Oscar E. Anderson, Jr., The New World 1939-1946 (Berkeley and Los Angeles: U. of California P., 1990), pp. 53I-6ri9. 
(or halt) their own individual atomic programmes and then trust to the Americans to renounce their own nuclear monopoly by turning it over, bag and baggage, to the UnAEC. To accept the Soviet proposal meant that the United States would have to hand over their nuclear technology, both civilian and military, to the UNAEC and then trust to the power of a treaty to exact compliance.

These quite distinct proposals had gained enormous international attention in the ten months between their initial articulation in June 1946 and the Lords' debate in late April 1947. Commentators, pundits, and experts (both real and self-appointed) had assessed their relative merits and weighed their prospects for success. By the time of the Lords' debate on the last day of April 1947, therefore, there was little new to be said but much hope that at least some kind of conceptual clarity could be brought to an often murky issue and that the diplomatic choices facing Britain and the rest of the world could be faced up to honestly and realistically. Such at least was the ambition of the peer who called for the debate, Cyril Garbett, the Archbishop of York and acknowledged spokesman of the Church of England on foreign affairs generally and atomic policy more specifically. ${ }^{29}$ And such was the urgency of the issue that Garbett's request for a full-scale debate on the international control of atomic power prompted both a full House and a powerful order paper of speakers.

Opened by Garbett, who asked "what progress, if any, has been made towards securing international control of atomic energy", the discussion quickly meandered into a broad survey of the horrors of atomic war, the merits and deficiencies of the American and Soviet proposals, the likelihood of the UNAEC's effectiveness, the true motives of Soviet foreign policy, and the proper role the British Government should play in the ongoing negotiations between East and West. ${ }^{30}$ As anticipated, some of the most respected voices in the upper chamber were heard, such as

29 Garbett's role in clarifying the Church of England's views on foreign and defence policy — and especially on the moral as well as practical issues raised by atomic energy —are described in Dianne Kirby, "The Church of England and the Cold War Nuclear Debate”, Twentieth Century British History, 4 (1993): 250-83, and Kirk Willis, "God and the Atom': British Churchmen and the Challenge of Nuclear Power 1945-1950", Albion, 29 (1997): 422-57.

30 "Atomic Energy Control", Parliamentary Debates (Lords), (5), I47 (30 April 1947): cols. $244-89$. 
those of the former Foreign Secretary Herbert Samuel, the erstwhile Master of Balliol Sandy Lindsay, the celebrated man of peace Viscount Cecil, the Oxford physicist and Conservative worthy Lord Cherwell, and the Secretary of State for Dominion Affairs Christopher Addison.

It was this intensely topical discussion that Russell chose to join. Speaking for only ten minutes - a mere nanosecond by Lords' reckoningRussell echoed many of the same points he had been making in lectures, broadcasts, and articles since the war's end. In particular, he stressed the urgency of the task facing the world's leaders. Granting that the challenge of fashioning an effective system of international control over atomic energy research and development was "extraordinary difficult", he insisted that failure to adopt some sort of scheme would lead "inevitably" to an atomic cataclysm. Virtually uniquely among contemporary British commentators, Russell claimed not simply that the proliferation of nuclear weapons among individual nations would make war more probable or even likely, but that conflict was ineluctably certain-a powerful assumption that would remain at the heart of his analysis of EastWest issues until his death. Importantly as well, Russell did not bother to argue for this strident claim. Offering no military analysis, no strategic overview, and no crisis assessment, he merely asserted that "we shall inevitably get an atomic war" if individual nations were permitted to develop their own nuclear programmes (cols. 273-4).

In order to avoid such an otherwise inescapable calamity, Russell urged the formation of an international agency possessing both monopoly control over weapons research, raw materials, and production facilities and unhindered authority to inspect and to punish all member nations without exception. As Russell conceded, the crucial question in the spring of 1947 was how to achieve this widely shared goal as quickly as possible. The obvious mechanism was to use the fledgling UNAEC, as the Baruch plan had proposed. The chief obstacle to this approach, however, was the veto power wielded by the permanent members of the Security Council. To Russell's mind, an international control regime that could not inspect and call to account any nation it chose when and how it chose was worse than useless. Instead, he proposed the creation of a parallel international organization devoted to atomic energy only with no member possessing a veto-although a full-fledged world government would have been more preferable still (cols. 274-5). At the moment, Russell observed, the outstanding diplomatic question was the attitude 
of the Soviet Union to such an organization. Ideally, the USSR would see the error of its ways and endorse either a reformed Baruch plan or a new regime along the lines of Russell's suggestion. Judging such an eventuality to be as unlikely as it was desirable, however, Russell then came to the crunch-was there any way to compel the Soviet Union's compliance? In particular, the question that had to be squarely faced was how to force Soviet acceptance of a strict regime of international control, inspection, and punishment. Repeating that the choice was between the creation of a genuine international inspectorate or the certainty of an atomic Armageddon, Russell asked his noble colleagues to be clearheaded enough to recognize that at the very least the threat and very probably the use of economic, diplomatic, and military sanctions against the Soviet Union had to be contemplated:

From all we know of Russia, inspection is the one thing they cannot stand, and I do not think they will accept it willingly.... Then the question arises, how much pressure of one sort or another it will be proper to use against them in order to compel them to act in a way which, quite clearly, is as much to their interest as to ours. (Col. 275)

At the end of the day, Russell concluded grimly, the question Britain and its allies had to confront in their dealings with the Soviet Union was as stark as it was inescapable: "I think the question will arise as to what degree of coercion it would be right and proper to apply" (col. 276).

Such an assertion - that some form of compulsion might well be required to force Soviet compliance with a non-proliferation regimewould of course be one which Russell would repeat, often among much misunderstanding, in the decade to come. Indeed, his alleged advocacy of a "preventive war" against the Soviet Union has remained perhaps the most enduringly controversial aspect of his entire public career. ${ }^{3 \mathrm{I}}$ In 1947, however, Russell's remarks in the Lords made little impact. Few of the speakers who followed him in the upper house bothered to refer to his intervention, and no one troubled to confront his dire question

${ }^{31}$ For a recent manifestation of this controversy, see the exchange of letters to the editor between Nigel Lawson and Nicholas Griffin in The Economist, 4, II, I8 and 25 Aug. 200I. Also useful are Ray Perkins, Jr., "Bertrand Russell and Preventive War", Russell, n.s. I4 (1994): 135-53, and David Blitz, "Did Russell Advocate Preventive Atomic War against the UssR?", Russell, n.s. 22 (2002): 5-45. 
directly. Nor did the press take up the issue. The Daily Telegraph, for instance, gave Garbett's remarks pride of place under a headline "Primate's Atom Bomb Warning", and offered only a twenty-nine word paraphrase of Russell's speech. And The Times, to cite another example, reported on Russell's intervention in its parliamentary column but confined its leading article on "Man and the Atom" to the arguments presented by Garbett and Addison. ${ }^{32}$

A full eleven years would pass before Russell again addressed the Lords. In the national life of Britain these were years of Indian independence and Palestine withdrawal, of Suez and Hungary, of nationalization and National Health, of economic recovery and "You Never Had it So Good", of hydrogen bombs and Sputnik, of Butskellism and Calder Hall. In Russell's own life these were years of divorce and remarriage, of the Nobel Prize and the Order of Merit, of "respectability" and financial security, of family travails and emotional upset, of "Man's Peril" and Pugwash, of foreshadowings of mortality and retreat to Wales. The two life courses came together in the late I95Os over the urgent issue of nuclear proliferation and superpower competition. In the decade since I947 relations between East and West had dramatically worsened. Not only had negotiations over the rival Baruch and Gromyko plans broken down irretrievably and even the pretence of East-West cooperation dissipated through successive confrontations over Berlin, Prague, Seoul, Suez, and Budapest, but the technology of killing had advanced from atomic to thermonuclear weapons and from long-range bombers to intercontinental missiles. Despite his advancing years and diminishing energies, Russell had remained a keen observer of these developments and had sent forth a battalion of words in speeches, articles, broadcasts, and interviews to alert the British public and political elite to the suicidal implication of these changes. ${ }^{33}$ If anything, the combination of approaching mortality and heightening international danger had given a new urgency to Russell's activities. Not merely had he written and broadcast heroically for a man in his ninth decade, but he had also organized-initiating the Russell-Einstein Manifesto, helping to transform that document into the Pugwash Movement, and serving as one of the

32 Daily Telegraph, I May 1947, p. 3, and The Times, I May 1947, pp. 5 and 8.

33 Russell's remarkable output in these years can best be traced in the magisterial Bibliography of Bertrand Russell. 
founders of the Campaign for Nuclear Disarmament. ${ }^{34}$ As intended, these activities brought Russell very much into public view and provided him with considerable publicity - something he coveted not simply out of vanity but also out of a desire to change the minds of British voters and policy-makers about their nation's foreign and defence policies. By the late spring of 1958 , therefore, Russell was immersed in what he judged to be the most pressing issue facing mankind, and a full-dress debate in the Lords on the prospect of world government led him to brave the considerable inconvenience of travelling from Wales to London in order to join what was certain to be a much publicized debate.

A Lords' debate on world government was the brainchild of William Beveridge, the eminent social scientist and author of the celebrated eponymous report on social insurance published in 1942. A regular attender in the Lords after his retirement from the mastership of University College, Oxford and ennoblement by the Attlee Government in 1946, Beveridge had used the upper house as a forum to keep the feet of both Labour and (after 195I) Conservative Governments to the social welfare fire. ${ }^{35}$ An excursion into foreign policy was, therefore, at once a departure for Beveridge and evidence of the growing concern over issues of nuclear proliferation and superpower rivalry in the Britain of the late I950s. Although Beveridge used the opportunity to open the debate to range widely over international affairs, the formal purpose of his motion was to ask that the Macmillan Government offer a comprehensive public statement of what diplomatic steps it either had taken or was contemplating taking in pursuit of its oft-avowed desire to promote world government. In a rare moment of self-deprecation-Beveridge was a man who took himself very seriously indeed-he conceded that "most of us in our time, myself included, have talked a certain amount of hot air about world government." Given the current diplomatic impasse, however, the time had come to descend "from hot air to brass tacks". In particular, Beveridge asked the government to answer two questions: "Just what do

${ }^{34}$ A glimpse into this activity may be found in Andrew Bone, "Russell and the Communist-Aligned Peace Movement in the Mid-I950s", Russell, n.s. 2I (200I): 3I-57; Richard Taylor, Against the Bomb: the British Peace Movement 1958-1965 (Oxford: Clarendon P., 1988); and Lawrence Wittner, Resisting the Bomb (Stanford: Stanford U. P., 1997).

35 Jose Harris, William Beveridge: a Biography (Oxford: Clarendon P., 1997), p. 475. 
they mean, and not mean, by 'world government' or a 'World Authority'. And what practical proposals have they for getting what they want?" 36

After this opening, the Lords leapt in to what became an extensive and uncommonly long discussion - with thirteen speakers and stretching to four hours (cols. 305-70). The roster of participants contained members of all parties and every background-including, besides Beveridge and Russell, one press lord (Viscount Astor), one Nobel laureate (Lord Boyd-Orr), one fellow of All Souls (Lord Brand), one former coal miner (Lord MacDonald of Gwaenysgor), one former governor of North Borneo (Lord Milverton), two Queen's Counsel (Lords Silkin and Chorley), one Tory grandee (the 5th Marquess of Salisbury), one former Indian Army officer (Lord Birdwell), one former Labour Cabinet minister (Viscount Stangate), and one future Prime Minister (Earl Home). As might have been expected given the diversity of the speakers and the complexity of the issue, the debate was as diffuse as it was lengthy, with individual peers riding their individual hobby horses from the iniquities of American foreign policy, to the horrors of world malnutrition, to the inadequacies of the United Nations, to the barbarities of the Soviet Union, to the glories of the British Empire.

For his part, Russell, then only four days shy of his eighty-sixth birthday, gave his least impressive performance in the Lords. Speaking for only twelve minutes, he allowed himself to stray into allusions far from the main point- touching, for example, on such distractions as the invention of gunpowder, Fabre's studies of insect behaviour, and contemporary speculation on the extinction of dinosaurs. Stripped of such diversions, the heart of Russell's brief intervention was at once familiar and dramatic: due to the invention of nuclear weapons humankind finds itself in "a race between prejudice and death" (col. 336). Unless the competitive, anarchic international order that had governed relations between states for centuries were to change and soon, another waralmost certainly a "great war"-will result. And that conflict, in turn, "would inevitably be a nuclear war" that would lead to the destruction of mankind. Describing this bleak prospect as "mathematically obvi-

36 "World Government", Parliamentary Debates (Lords), (5), 209 (I4 May 1958): col. 306. 
ous", Russell reasoned that "the only way of survival for our species" is therefore to avoid such a conflict. And the only way to do that is to create a world authority and place "a monopoly of all the serious weapons of war in the hands of that World Government" (cols. 334-5).

Russell was quick to concede that the creation of such a regime would be both slow and fraught with difficulties and objections - especially in the polarized international situation of the late I950s. The alternative, however, was the eradication of human life on the planet. Thus every effort, no matter how demanding, had to be made, beginning with the radical "change in mental habits" that would be required among peoples and governments everywhere. In particular, Russell asserted, nations and nationalities had to be made to understand that "the interests of all mankind are identical in this matter" (cols. 333-4). Clearly, he granted, "gradual approaches are absolutely necessary" to build the required trust and understanding. Fortunately, he observed, such interim steps were at hand-beginning with the "considerable reform of the United Nations", extending to the cooperative development of the Arctic and Antarctic, continuing to schemes to promote arbitration of disputes between nations, and culminating in the establishment of a world government. To be sure, Russell concluded with his normal rhetorical flourish, such developments would be neither quick nor easy. The price of failure or impatience, however, was "that, before the end of the present century, no human beings will exist" (cols. 335-6). ${ }^{37}$

Within the Lords' chamber, Russell's appearance was a dramatic event in that somewhat somnolent body. Although neither the oldest nor the longest-serving peer, Russell was indisputably one of the most distinguished, controversial, and senior members of the body. His recent public renown as an anti-nuclear campaigner as well as his eleven-year hiatus from the Lords guaranteed a large and respectful audience. And, indeed, in the words of one observer, the House "greeted him with prolonged cheers and listened in grave silence to his every word." 38 Unfortunately for Russell, only one of his colleagues engaged directly with his remarks. To the former Labour activist and academic lawyer

37 Testimony to Russell's longevity was his reference to the long-defunct League of Nations at one point in his remarks (col. 335).

${ }^{38}$ George Holt, "Humanity May End This Century Says Russell”, News Chronicle, I5 May 1958, p. 7. 
Lord Chorley, Russell's words had constituted an "extraordinarily cogent and convincing speech" (col. 340). To the rest of the House, regardless of their respect for his advanced years and intellectual standing, more pressing questions about the current state of Soviet-American relations and the technical difficulties inherent in the establishment of a world government gained pride of place in their remarks.

Outside the upper house, press coverage was more sympathetic. The left-leaning News Chronicle, for example, judged Russell's appearance to be worthy of a front-page column by its chief political reporter, George Holt. Under the headline "Russell: World Can't Wait", Holt described Russell's remarks as "a dramatic intervention" and made a great deal of the celebrity value of the moment: "Earl Russell, who will be 86 on Sunday, made his first speech in the Lords last night for II years." On an inside page, the paper ran a picture of Russell and offered long excerpts from his speech under the headline "Humanity May End This Century Says Russell". ${ }^{39}$ So, too, did the Manchester Guardian strain to capture the moment: "Lord Russell was greeted with prolonged and enthusiastic cheers from both sides of the House when he rose to speak." For its part, The Times chose to highlight Russell's remarks - "Myth of Safety in Strength, Earl Russell's Fears"-in its parliamentary report rather than on the first news page. $4^{40}$ Pride of place there and on the editorial page went to coverage of what proved to be the death throes of the unlamented French Fourth Republic.

Russell's final appearance in the Lords came in a February 1959 debate on nuclear disarmament. The third such discussion in eighteen months but the first Russell had attended, it was organized by one of Russell's closest CN D associates, Ernest Simon, who had been ennobled in 1947 as Lord Simon of Wythenshawe after a long career of Labour activism. ${ }^{4 \mathrm{I}}$ Born into the prosperous Liberal world of the Manchester business elite, Simon proved at once adept at directing the family engineering firm and dedicated to social reform and humanitarian causes. Elected Lord Mayor of Manchester in I92I and MP in I923-24 and I929-3I, he was a skilled and versatile public figure-serving for example, as chairman of the в В С

39 News Chronicle, I5 May 1958, pp. I and 7.

40 Manchester Guardian, I5 May 1958, p. 2; The Times, I5 May 1958, p. 7.

${ }^{4 \mathrm{I}}$ Mary Stocks, Ernest Simon of Manchester (Manchester: Manchester U. P., 1963) remains the best study of Simon's long life. 
in 1947-52 and of the Manchester University Council in 194I-59. A passionate opponent of nuclear weapons in any guise, Simon was an early recruit to $\mathrm{CND}$, serving on its executive committee from the outset and offering valued tactical and financial aid to the fledgling organization until his death in 1960.

Sharing the view of other CND leaders that their organization was being deliberately ignored by an unsympathetic media, Simon and Russell had hatched a plan in December 1958 to exploit their joint membership in the Lords in order to stage a full-dress debate on nuclear disarmament in the upper house-one certain to win much press attention as a matter of course. At the time, however, the Macmillan Government had asked them to postpone their motion in deference to the then ongoing us-Soviet negotiations in Geneva concerning the suspension of nuclear weapons tests-a request to which both Simon and Russell had acceded. ${ }^{42}$ By February 1959, however, those ill-starred negotiations had ended in recrimination and the Government had allowed Simon and Russell's motion to be placed on the order paper.

The close cooperation between Simon and Russell in organizing the debate was made plain from the very outset of Simon's remarks. Rising to put his motion, he told the House that that proposal had two simple goals: "to persuade Her Majesty's Government to take definite action to stop the spread of nuclear weapons to other countries by ourselves offering to forego, and abandon the use of, such weapons" and, second, "to persuade the United States of America and Russia to co-operate in helping the United Nations to control and enforce the necessary treaties". ${ }^{43}$ As Simon hastened to explain, this controversial proposal had first been offered "by my noble friend Lord Russell ... a year ago and it has never been discussed in Parliament ... [and] only very slightly in the press" (col. 72). Moving on to praise Russell's recently published Common Sense and Nuclear Warfare as "an admirable example of the way in which a subject of this magnitude and of this terror should be discussed", Simon urged the British Government to take the initiative in a

${ }^{42}$ Under the Lords' rules, this request for postponement was more a courtesy than an actual choice. The Macmillan Government could simply have refused to put the motion on the order paper without any explanation whatsoever.

43 "Nuclear Disarmament", Parliamentary Debates (Lords), (5), 214 (II Feb. 1959): col. 72 . 
bold new strategy for peace. Instead of wrangling endlessly and fruitlessly over the details of inspection regimes and disarmament proposals, Britain should destroy its own nuclear stockpile, renounce its intention of ever reconstituting it, and become the founding member of "a nonnuclear club to stop the spread of the bomb". "That", he claimed with grim understatement, "is the single object of the Motion to-day" (cols. 72-3).

Describing the issue of nuclear disarmament as one of "desperate importance, complexity and difficulty", Simon defended his proposal by offering what were already well on their way to becoming standard CND arguments-Britain ("this crowded island") was uniquely vulnerable to nuclear attack ("in greater peril than any other part of the world"); a war fought with hydrogen bombs would destroy human life on the planet ("radiation on a sufficiently large scale in an H-bomb war might destroy the human race"); the proliferation of nuclear weapons beyond the Soviet Union, United States, and Britain would dramatically raise rather than lower the chances of an all-out nuclear war ("will almost certainly be disastrous"); left to themselves the Americans and Russians ("in a deadly embrace") will be incapable of destroying nuclear weapons and thus of saving humankind ("from otherwise certain extinction") (cols. 74-5 and 78). As Russell had urged in repeated articles, broadcasts, and interviews and as Simon now reiterated, Britain was well positioned to lead the world away from annihilation and towards peace. As Simon explained to his noble colleagues, the British Government needed to muster the courage to take five unprecedented steps: first, "to form a non-nuclear club of all the industrial nations except the two giants"; second, "to get the present non-nuclear Powers to sign a treaty not to own, manufacture or use nuclear weapons"; third, "as part of that treaty and, of course, contingent on it, Britain would cease to manufacture nuclear weapons, would never use them and would undertake to destroy her stocks"; fourth, "to approach the United Nations, to ask them to take responsibility for inspection and enforcement"; fifth, "to urge the two giants jointly to give active help to the United Nations and, also, to undertake not to give nuclear weapons to any other country". Conceding that the obstacles hindering the adoption of this policy were "immense" and acknowledging that "the action we propose is contrary to the present policy of the Government and of the Opposition", Simon nonetheless concluded his opening remarks by urging his colleagues to 
devote their full attention to "this desperately urgent subject" and to help in "clarifying [the] complicated issues" involved (ibid.).

Testimony to the significance of the moment was the decision of the defence spokesmen of both major parties to reply to Simon at the very outset of the debate. Speaking for the Conservatives was the then Leader of the House and Commonwealth Secretary and future Foreign Secretary and Prime Minister, the Earl Home. To Home's mind-and, by extension, to that of the Macmillan Government-Simon and Russell's proposal was "one born of despair" and not of hope and one which "as it applies to the strategic position in Western Europe would certainly give a net advantage to the Communist side." What was required was not renunciation but rededication - "unceasing" work through the United Nations as well as bilateral negotiations between the United States and the Soviet Union (cols. 86 and 83). For his part, the former Labour Defence Secretary Viscount Alexander of Hillsborough hastened to clarify that the Labour Party also did not accept and would not endorse Simon and Russell's motion. Acknowledging the recent fractious discussion at the Labour Party conference at Brighton during which nuclear issues had been passionately and divisively debated, Alexander repeated the recently reaffirmed party line-that Britain remain in NATO, that it continue to deploy its own independent nuclear deterrent, and that it support the general direction of American nuclear diplomacy. Britain, Alexander concluded, must not adopt a policy which mandates that it simply "hide behind the Americans and their bomb for our security in the future." Such an ignoble policy was not the intention of the Labour Party and would never be the position of any Labour Government (cols. 90-I).

After this high-powered opening, the Lords began an extensive and lengthy exchange-with twenty total speakers and stretching for over six hours. As with the discussion on world government the previous May, the roster of participants contained peers of all parties and every background —including, besides Simon and Russell—one Grenadier Guardsman (Lord Rea), one former political journalist (Lord Henderson), one Hereditary Royal Standard-Bearer for Scotland (Earl Dundee), one Nobel Laureate and Master of Trinity (Lord Adrian), one former pupil of Diego Rivera (Earl Huntingdon), one former permanent official (Lord Strang), one Tory grandee (the Ioth Earl of Bessborough), one former mayor of King's Lynn (Lord Wise), two former Labour cabinet ministers 
(Viscount Alexander and Lord Wilmot), two former foreign correspondents (Lords Coleraine and St. Oswald), three bishops (of Manchester, Portsmouth, and Chichester), and three recidivists from the 1958 debate (Home, Boyd-Orr, and Birdwood). As much of the subsequent press commentary confirmed, the debate presented the House of Lords at its very best - sharp, attentive, non-party, and animated by a desire to understand rather than a need to self-aggrandize.

For his part, Russell easily rose to the occasion and delivered what would be his finest speech in the upper house. Although speaking early (fifth in order) and relatively briefly (eighteen minutes), he offered both an impassioned defence of the arguments presented in the motion and a pointed reply to the objections raised by earlier speakers. Russell began by responding directly to the claim put forward by Alexander that the proposed non-nuclear club amounted to "a unilateral renunciation of possession of the bomb". In fact, Russell replied, "there is no suggestion in [Simon's] Motion of a unilateral renunciation of the bomb by us" but rather of an "offer to renounce it in conjunction with all the Powers other than the United States and the U.S.S.R.” As to the suggestion made by Home that in a non-nuclear Europe "the net result would be to put more power in the hands of Germany", Russell confessed his utter bewilderment: "I think we must consider that that argument is not really one that is germane to what we are proposing." And most exasperatedly, Russell turned to the common objection that he and other critics of nuclear weapons had been hearing since war's end-that the time is not right "for taking the first step". After thirteen years, Russell observed, such a claim "is a little tiresome" and more than a little disingenuous (col. 98).

In his own, brief arguments in favour of the motion, Russell stressed two points. First, that the steps outlined in the motion constituted not the last but only "the first move, and I hope a practicable move, in a long campaign", the ultimate objective of which was "to ensure the continued existence of the human race". Such an objective, he repeated, required not simply the transient disappearance of nuclear weapons which, invented in one war, could be re-invented in another, but the end of war itself (ibid.). Second, Russell warned against "a certain tendency to underestimate the evils that would result from a really serious nuclear war." Citing statistics from the American Federal Civil Defence Association that 72 million deaths and 2I million injuries could be 
expected even in that vast country in case of a nuclear war, Russell pressed the urgency of the moment on his noble colleagues. "I think", Russell observed trying to strike a balance between rhetorical flourish and sober warning, "that unless something rather drastic is done, it is at least as likely as not that no Britons will be alive at the end of the present century" (col. 99). In such circumstances, he urged in conclusion, it was the duty of humankind everywhere to make every effort to rid the world of both the means and the motives to war-a task as demanding as it was essential:

[It] is not an easy effort. But we have to make the effort; and those of us who cannot make that effort are contributing their little bit towards the extinction of the species. (Col. IO2)

Although Russell left the chamber soon after the conclusion of his remarks and delegated the final summing-up to Simon-a mere pup of 79-his words reverberated around St. Stephens for the next four-and-ahalf hours of sustained and often impassioned discussion. Few of the succeeding fifteen speakers failed to pause to praise Russell's sincerity, longevity, and eloquence; many fewer, however, hastened to express their agreement with him. By the end of the debate, which roamed freely from the niceties of deterrence theory to the dangers of radioactive fallout to the sinfulness of war to the depredations of the Soviets to the virtues of NATO to the faults of the Americans to the metaphysical nature of evil, the sense of the House was very much what Russell had huffed at as "tiresome"-in support of the ultimate goal of nuclear disarmament but in opposition to any specific first step to that end.

As has been seen, the explicit purpose behind Simon and Russell's staging of a Lords' debate on nuclear disarmament had been to win wide press and public attention to their proposal. By an unhappy turn of fortune's wheel, however, the long-simmering conflict in Cyprus came to the boil in early February and the headlines of the British press on the morning after the debate blared "Cyprus Showdown" and "Cyprus Sell-Out" rather than news of a nuclear initiative by an octogenarian peer, no matter how eminent. ${ }^{44}$ So too did the diarists and leading article writers of Britain's major dailies devote their attention to Arch-

${ }^{44}$ Daily Herald, I2 Feb. 1959, p. I, and Daily Express, I2 Feb. 1959, p. I. 
bishop Makarios rather than to Lords Simon and Russell. To be sure, the Lords' debate won careful coverage on various papers' parliamentary pages. The Times, for example, offered a closely detailed account of the debate, running to nearly an entire page of close print under the headline "Stark Choice Facing the Nuclear Powers: Gesture of Renunciation by Britain Opposed". The paper offered an unusually full extract of Russell's speech, even remarking on the cheers that greeted the end of his remarks. ${ }^{45}$ For its part, the Manchester Guardian put its coverage on its first page: "Peers Face Nuclear Facts of Life: Power of a Moral Gesture". Although most of the article focused on the remarks of Simon, Home, and Alexander, Russell's intervention was mentioned respectfully. And in a continuation on the second page headed "Non-Nuclear Club' Rejected as Policy of Despair”, Russell's provocative claim that "unless something drastic is done ... no Britons will be alive at the end of the present century" was quoted in full. ${ }^{6}$ The Conservative-minded Daily Express's parliamentary correspondent, by contrast, offered a somewhat admiring yet mocking account of Russell's performance. "Earl Russell is 86. But what a sprightly speaker he is", the reporter observed by way of preface to a long extract from Russell's speech. "But would you believe it. Just as the crowded House was listening with the closest attention to hear how to ban war, what should Earl Russell do but finish his speech and sit down." 47 For its part, to offer a final example, the Labour Daily Herald turned Russell's observation that "we had a terrible experiment not so long ago of a Government which would have destroyed the human race rather than submit" into an eye-catching headline: "Hitler Would Have Used H-bomb Rather Than Submit". The Herald's chief parliamentary correspondent, Deryck Winterton, had then gone on to present a respectful description of Russell's appearance:

in his gentle, undramatic voice, 86-year-old Earl Russell, better known as Bertrand Russell, made this point in the House of Lords last night to emphasize the menace of nuclear weapons in the hands of an "irresponsible government". ${ }^{48}$

45 The Times, I2 Feb. 1959 p. 3.

${ }^{6}$ Manchester Guardian, I2 Feb. 1959, pp. I-2.

47 Daily Express, I2 Feb. 1959, p. 2.

${ }^{8}$ Daily Herald, I2 Feb. 1959, p. 7. 
With such uneven coverage Russell and Simon had to be content. Only the Manchester Guardian of London's major dailies used the occasion to offer a leading article on nuclear disarmament- "The Balance of Terror"-but even its sympathetic editorialist failed to mention Russell more than in passing.

Six speeches in 39 years. Although not up to the genuine backwoods standards of Lord Oranmore and Browne-who sat in the upper house for 72 years without ever once rising to his feet-Russell's participation in the Lords must be described as meagre. As such statistics make plain, for all his occasional attempts at a parliamentary career Russell was not a natural political animal. To be sure, he was not immune either to the flattery or to the self-importance long associated with political life and he most certainly liked the sound of his own voice, but he well understood that the natural outlet for that voice was the printed page. As he reiterated throughout his public life, his "proper job" was writing and his instinctual mode of expression was the written rather than the spoken word.

For all his egotism and personal ambition, moreover, Russell was constituted not for authority but for opposition. He was not an organizer by temperament and lacked the gifts of intrigue and horse-trading that are indispensable to political figures in modern democratic states. Not for Russell, then, the career not merely of his grandfather or brother, but even that of Beveridge. Neither minor office nor regular attendance tempted him-just as he had foreseen upon inheriting his title in I93I.

Russell's time in the Lords also straddled a revolution in mass communication. Not merely did radio and, especially, television displace newsprint, but Russell proved remarkably adept at both new media-as broadcaster, interviewee, and star performer. Such appearances won him an audience far wider than any provided by the Lords-whose debates were not yet broadcast on radio or television and were increasingly ignored by a press which found it more compelling to put a microphone in front of a politician rather than to print a lengthy account in the paper. Tellingly, when Russell chose to issue his famous warning "Man's Peril" in December 1954, he did so not in the Lords but over the в в С. 
His later commitment to direct action was thus but an extension of this earlier behaviour, choosing not to rise to his feet in St. Stephen's Palace but to lower to his seat in Trafalgar Square.

Nor, it must be said, was Russell much of an admirer of the Lords as an institution. Even before his deep alienation from the British political establishment in the 1960s, he paid scant attention to the Lords. Not merely does he not appear to have attended its sessions except to speak, ${ }^{49}$ but he mocked the body when asked in 1947 to propose suggestions for its reform:

My views on the subject are simple. I think a second chamber a mistake, but if there has to be one it is better it should be an indefensible abuse. Any imaginable reformed second chamber would be a more formidable obstacle to progress than the present House of Lords..$^{\circ}$

To many in Britain, especially among his political allies and friends, Russell's deliberately modest role in the Lords stood as a disappointment and a lost opportunity. In an admiring Sunday Times profile in October I949, for example, that paper regretted his lack of involvement in the upper house: "It is a pity that he does not speak in the House of Lords." ${ }^{11}$ And the eminent nutritional scientist and man of peace John Boyd-Orr, to offer another example, not simply regretted Russell's lack of participation but went so far as to urge him to further involvement. ${ }^{52}$

Russell's nearly four decades in the Lords thus seem a missed opportunity. Surely it is not just students of Russell who lament not hearing his contributions to the controversial debates on nationalization and national health, Suez and Palestine, divorce and education reform,

49 By their very nature, Russell's non-speaking appearances in the Lords are difficult to document. One such is recorded by Russell himself in recalling his last contact with John Maynard Keynes: "The last time that I saw him was in the House of Lords [on I8 December 1945] when he returned from negotiating a loan with America and made a masterly speech recommending it to their Lordships" (Auto., I: 72).

5o Bertrand Russell, "Should We Abolish the House of Lords?" Labour Forum, I, no. 4 (1947): IO-II. Another example of his lack of respect for the House of Lords is the American article, "British Aristocracy Will Last as Long as the Monarchy", Jewish Daily Forward, I8 Sept. 1927, p. EI.

s1 Sunday Times, 9 Oct. 1949, p. 6.

52 John Boyd-Orr, As I Recall (New York: Doubleday, 1967), pp. 224-5. 
Indian independence and conflict in Korea, the formation of NATO and the implementation of the Marshall Plan that convulsed the upper house in the I940s and 1950s. But Russell's appearances in the Lords, however fitful, did allow him to make plain those issues in which he was most interested-and which proved, overwhelmingly, to be questions of war and peace, whether in 1937, 1945, 1947, or 1958/59. His seat in the Lords thus presented Russell not just with a national forum but also with the opportunity to make clear-even to himself-his own political priorities and to give evidence of those issues which most strongly engaged his emotions and fired his intellect. 